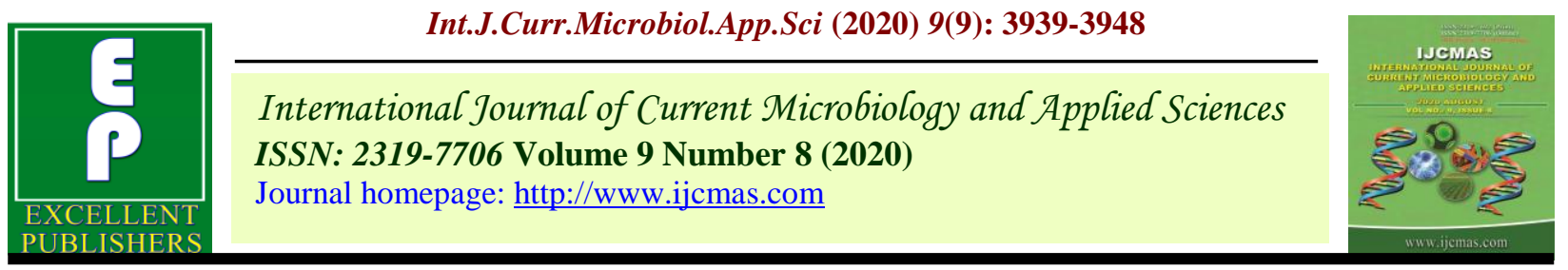

Original Research Article

https://doi.org/10.20546/ijcmas.2020.908.453

\title{
Biological Control of Rice Blast Disease (Pyricularia oryzae) using Bacterial Consortia Formulation in Malwa Region (Punjab)
}

\author{
Nalini Singh* and Jasvir Singh Brar \\ Guru Kashi University, Sirsa-Sardulgarh Rd, Talwandi Sabo, Punjab 151302, India \\ *Corresponding author
}

\section{A B S T R A C T}

\begin{tabular}{|l|}
\hline Ke y w o r d s \\
Bacillus spp., Rice \\
Blast disease, \\
Consortium of \\
bacteria, \\
Streptomyces spp, \\
Pyricularia oryzae
\end{tabular}

Rice blast disease are a serious and recurrent problem in all rice-growing regions of the worldwide, and the disease is extremely difficult to control. Rice blast caused by Pyricularia oryzae and it is control by two methods i.e. chemical control and biological control. The present study was aimed to explore the potential of bacterial consortia that may control rice blast disease on rice plants. In this study, the rice blast disease has control by the various bacterial cultures and their consortium i.e. Bacillus subtilis, bacillus cereus, streptomyces griseocarneus, streptomyces albidoflavus, and combination for their suppression ability against $P$. oryzae under in-vitro conditions and green house in GKU campus. The results showed that streptomyces albidoflavus (A1) and combination of streptomyces albidoflavus, Bacillus subtilis and bacillus cereus $(\mathrm{A} 1+\mathrm{A} 3+\mathrm{A} 4)$ significantly reduced the mycelial growth of $P$. oryzae with the percentage inhibition of 55.3\%$24.3 \%$ and $90.0 \%-89.0 \%$, respectively.

\section{Introduction}

Rice (Oryza sativa L.) is the major staple food for nearly one half of the world's population (Dobermann and Fairhurst, 2002). India had an area of over 45.0 million hectare under rice, producing over 200 million tonnes of paddy in 2015. Total production of rice during 2019-20 is estimated at record 116.42 million tonnes (Welfare and Welfare, 2019). Moreover, in world production of rice was 500.8 in 2019-2020 (FAO, 2020). Rice crop occupied 31.03 lakh hectares in Punjab with total production of 191.36 lakh tonnes (128.2 lakh tonnes of rice) during 2018-19. The rice blast (Pyricularia oryzae) has been reported as the most destructive disease, causing losses worth of multi-million dollars, each year (Dean et al., 2012). Varied types of symptoms, such as leaf blast, nodal blast, collar rot, neck rot, and panicle rot, have been named based on plant parts infected. Furthermore, human exposure to pesticides may cause poisoning and harmful sideeffects to vital organs and/or biological processes (Law et al., 2017; Raman and Muthukathan, 2017). Pesticide poisoning is a significant occupational health hazard in 
developing countries to control the rice blast disease. The fungicides application shows their adverse effects on environment as well as beneficial soil microorganisms. A number of microbial agents have been reported to be effective as biological control of plant diseases. Biocontrol approach for managing blast disease was considered a good alternative. Production of secondary metabolites in bacteria and actinobacteria has used as antibiotics, Fe-chelating siderophores, and cyanide are most often associated with fungal suppression. As per literature survey, it is concluded that actinobacteria specially streptomyces and bacillus spp. were much antagonistic rather than others. The success of biological control may depend on suitable formulations as well as survival of the microbial agents. Bacteria and actinobacteria acts as biological control agents have shown advantages over fungal pathogens i.e. the bacterial cells mass can be produced more easily and faster than the fungus. In addition, they are generally effective when applied as a preventive application to suppress the disease (Suryadi et al., 2011).

This study was aimed to test the efficacy and potential of bacterial consortia (Streptomyces albidoflavas strain MK121, Streptomyces grierocarmus strain MK186, Bacillus subtilis strain MK145, Bacillus cereus strain MK148) using various formulations as biological control agents to control rice blast disease caused by $P$. oryzae.

\section{Materials and Methods}

\section{Isolation and in-vitro screening of bacterial consortium against rice blast}

The soil bacterial isolates viz. MK121, MK186, MK145, MK148.Stock cultures of bacteria were prepared using Nutrient Broth (NB) medium. Colonies were selected, purified and used for further studies. The list of bacterial isolates and their origin is presented in Table 1.

\section{Dual culture test formulative bacteria against Pyricularia oryzae}

Bacterial consortia isolates were grown on YMG and NB medium in the Erlenmeyer flask until the population reaches $10^{6}-10^{7}$ $\mathrm{CFU} / \mathrm{ml}$ incubated at room temperature for 24-48 hours, then stored in a refrigerator at $4^{\circ}$ C. Mixing the bacterial consortia was done as indicated in Table 2.

$P$. oryzae fungus was isolated from blastinfected rice cv PB 1121 growing in Guru Kashi University research field. Pure cultures of $P$. oryzae were grown on Petri dishes containing Potato Dextrose Agar (PDA) medium and incubated for one week in BOD at $28 \pm 11^{\circ} \mathrm{C}$ temperature. After that in this added with $2 \mu \mathrm{g} / 50 \mathrm{ml}$ streptomycin to eliminate growth of spores then washed with sterile distilled water containing $0.2 \%(\mathrm{v} / \mathrm{v})$ Tween 20. Spore suspension was then filtered and collected in sterile Erlenmeyer flasks, the spore density was observed by haemocytometer. The bacterial consortia isolates and mix consortium were screened for their suppression ability against rice blast pathogen, $P$. oryzae by dual culture technique following the method of Rabindran and Vidyasekaran (1996). Bacterial isolate used as Bacterial Whole Cell Cultures (BWC) was streaked at one side of petri dish $(3 \mathrm{~cm}$ away from the edge) containing PDA. Five mm mycelial plug from seven-day-old PDA cultures of $P$. oryzae were placed at the opposite side of Petri dishes (diameter $9 \mathrm{~cm}$ ) perpendicular to the bacterial streaks. The treatments was completely randomized design with three replications. The control plates were incubated at $28^{\circ} \mathrm{C}$ fungal mycelia completely covered the agar surface. Observations were done by measuring inhibition zone and mycelial growth of the 
pathogen, and percent inhibition of pathogen growth was calculated using formula:

$$
\mathrm{I} \%=\mathrm{C}-\mathrm{T} / \mathrm{C} \times 100
$$

where $\mathrm{I}=$ inhibition of mycelial growth, $\mathrm{C}=$ growth of pathogen in the control plate $(\mathrm{cm})$ and $\mathrm{T}=$ growth of pathogen in dual cultures (cm).

\section{Culture filtrates of the selected best formulation}

Prior effective dual culture active bacteria consortia were selected and tested for their suppressing ability by using bacterial culture filtrate in sequence an agar plug $(9 \mathrm{~mm}$ diameter) taken from active growing fungal culture was placed on the surface of the plateenhancing medium. Bacteria initially were grown on YMG and NB medium and incubated for 48 hours. One $\mathrm{ml}$ of culture suspension was centrifuged at $10000 \mathrm{rpm}$ for 20 minutes. Then through cork bore diameter of $0.5 \mathrm{~cm}$ into the PDA medium in Petri dishes. Further than $100 \mathrm{~mL}$ supernatant of bacteria filtrate was transferred into a petri dish and then poured to the homogenized PDA medium. Plates inoculated with fungal agar plugs alone were used as control. each treatment was performed thrice replications. The entire Petri dish containing treatment was incubated for one week in BOD at $28 \pm 1^{0} \mathrm{C}$ temperature, and then the radial growth of P.oryzae was measured and percent inhibition of pathogen growth was calculated (Kumar et $a l ., 2000$ ) shown in figure 2.

\section{Efficacy of Bacterial Consortia against $P$. oryzae (Green House Test)}

Various formulations were assessed for their effect on rice blast under greenhouse conditions. A pot culture study was undertaken with the following treatments Rice seeds cv. PB1121 was sown pot containing sterilized soil and humus of decayed leaves $(3: 1 \mathrm{w} / \mathrm{w})$ in greenhouse conditions. Seeds were planted $3-4 \mathrm{~cm}$ below soil surface per pot. In three leaves-stage, they were separated in ten groups with thirty pots in each and treated with: A1, A2, A3, A4, A5, A6, A7, A8, A9 treatments as follow in table 2 .

The carrier materials was studied that talc and suspension and its composition and mixing process of materials as follows: (a) talc: 300 $\mathrm{ml}$ suspension of bacterial isolates, $1 \mathrm{~kg}$ of talc, $10 \mathrm{~g}$ of carboxymethyl cellulose (CMC), $15 \mathrm{~g}$ of $\mathrm{CaCO}_{3}$, (b) suspension: $300 \mathrm{ml}$ of bacterial suspension $\left(10^{9} \mathrm{CFU} / \mathrm{ml}\right)$. Prior to transplanting the rice seedlings were immersed in talc for one night and suspension was given for 3 hours respectively. The inoculation of $P$. oryzae was done by spraying spores with a density of $5.0 \times 10^{8}$ spores $/ \mathrm{ml}$ and placed under humid conditions with high relative humidity. Rice plants untreated with $P$. oryzae infection and formulations served as healthy control moreover plants inoculated with $P$. oryzae alone as untreated control without formulation. $100 \mathrm{ml}$ of bacterial consortia formulations was applied on rice plants with three times spraying at 3 days, 7 days, and 9 days after inoculation (D.A.I).

Data was taken from eight plants (4-5 leaves per plant) for each treatment (Suryadi et al., 2013) Observations was done at 14 D. A.I based on blast disease assessment given by the standard evaluation system of IRRI (1996). Microscopy showed the spores morphology was a pear like shaped with hyaline brownish colour (Figure 1) under camera Lucida. Then the severity of blast is calculated using the formula:

$\mathrm{DS}=\sum \frac{\mathrm{n} \times \mathrm{v}}{\mathrm{N} \times \mathrm{V}} \times 100$

$\mathrm{DS}=$ disease severity

$\mathrm{n}=$ number of leaves infected by blast

$\mathrm{v}=$ value score of each category attack 
$\mathrm{N}=$ number of leaves observed

$\mathrm{V}=$ value the highest score

\section{Statistical optimization}

Data from both trials (in vitro +in vivo) were subjected to an analysis of variance (ANOVA) to determine the significance of incidence and intensity by the SPSS. The experimental repeats were analyzed separately. This is also used in the context of analysis of variance (ANOVA) for judging the significance of more than two sample means at one and the same time. It is also used for judging the significance of multiple correlation coefficients.

\section{Results and Discussion}

Active bacteria consortia isolates grow within 48 hours in Petri plate on Streptomycetes Agar, Oat Meal Agar and NA media, while the $P$. oryzae fungus grow up on PDA media and pure culture was obtained. The mycelium of $P$. oryzae was shows white colour in early growth and became dark within one week. Observation of fungal spores under light microscopy the spores morphology was pear shaped with hyaline brownish colour (Figure 1-4).

\section{Dual culture test of formulative bacteria against Pyricularia oryzae}

In this Dual culture test of bacteria consortia against the rice blast pathogen revealed that the inhibition of rice blast ( $P$. oryzae). Among these isolates, MK121 was found to be highly effective in controlling the pathogen with inhibition of $55.3 \%$. The other effective strains were followed by MK148 and MK186, showed inhibition of test fungus in the range of $36.3 \%$ to $35.0 \%$ (Table 3 ). Results relevant to dual culture tests indicated the presence of inhibitory zones on Petri plate. This is evident of the formation of inhibitory activity against
$P$. oryzae fungi by bacteria. The result revealed that isolates cultures of (A7) showed high degree of inhibition with the mean average of the inhibition area of $38.6 \%$, respectively. The untreated control showed no inhibitory activity of $P$. oryzae, which indicates the maximum growth of fungus.

\section{Culture filtrates of the selected best formulation}

The formulation of biocontrol agents, the inhibition test of further selected bacterial isolates using MK121 (A1) and MK121, MK186 and MK148 (A7) on NA medium containing supernatant of both treatments showed the average of $P$. oryzae radial growth of $12.40 \mathrm{~cm}^{2}$ and $24.2 \mathrm{~cm}^{2}$ with the inhibition of $90.59 \%$ and $89.00 \%$, respectively (Figure 2); while on the control treatment, $P$. oryzae can grow up to $76 \mathrm{~cm}^{2}$ across the surface of Petri dish. This confirms inhibitory activity of bacterial isolates against P. oryzae.

\section{Efficacy of Biocontrol agents against $\boldsymbol{P}$. oryzae (green house test)}

Observation of the effect of carrier formulations application agents was performed at 14 days after inoculation. Rice blast fungus ( $P$. oryzae) showed spots with brown edges; white or grayish center patches. The shape and color of spots varied depending on environmental conditions, and the degree of rice resistance.

Following the assessment of blast disease based on IRRI (1996); A1 and A7 treatments in the form of a suspension carrier provides slower blast disease progression than other formulas with the percentage of blast severity was $11.8 \%$ and $19.3 \%$, respectively; whilst on untreated control, the blast severity was $74.0 \%$ (Table 4). 
Table.1 List of isolates used in this study

\begin{tabular}{|l|l|l|l|}
\hline S.No. & Bacterial isolates & Host & Source \\
\hline $\mathbf{1}$ & Streptomyces albidoflavas strain MK121 & Chilli & Soil \\
\hline $\mathbf{2}$ & Streptomyces grierocarmus strain MK186 & Rice & Soil \\
\hline $\mathbf{3}$ & Bacillus subtilis strain MK145 & Tomato & Soil \\
\hline $\mathbf{4}$ & Bacillus cereus strain MK148 & Rice & Soil \\
\hline
\end{tabular}

Table.2 Treatment code and bacterial isolates used in the study

\begin{tabular}{|l|l|}
\hline Treatment code & Isolates/mix cultures \\
\hline A1 & Streptomyces albidoflavas strain MK121 \\
\hline A2 & Streptomyces grierocarmus strainMK186 \\
\hline A3 & Bacillus subtilis strain MK145 \\
\hline A4 & Bacillus cereus strain MK148 \\
\hline A5 & $\begin{array}{l}\text { Streptomyces grierocarmus strainMK186+ Bacillus subtilis strain MK145 } \\
\text { Streptomyces albidoflavas } \text { strain MK121 }\end{array}$ \\
\hline A6 & $\begin{array}{l}\text { Streptomyces albidoflavas strain MK121+ Bacillus subtilis strain MK145+ } \\
\text { Bacillus cereus } \text { strain MK148 }\end{array}$ \\
\hline A7 & $\begin{array}{l}\text { Bacillus subtilis strain MK145+ Streptomyces grierocarmus strainMK186+ } \\
\text { Bacillus cereus } \text { strain MK148 }+ \text { Streptomyces albidoflavas } \text { strain MK121 }\end{array}$ \\
\hline A8 & Untreated control (water) \\
\hline A9 & \\
\hline
\end{tabular}

Table.3 Effect of bacterial consortium used on the pathogen growth inhibition

\begin{tabular}{|l|c|c|}
\hline $\begin{array}{l}\text { Treatment } \\
\text { Codes }\end{array}$ & $\begin{array}{c}\text { Radial growth of } \boldsymbol{P} \text { oryzae } \\
(\mathbf{c m}) \mathbf{\text { SD }}\end{array}$ & $\begin{array}{c}\text { Mean inhibition over control } \\
(\boldsymbol{\%}) \pm \mathbf{S D}\end{array}$ \\
\hline $\mathbf{A 1}$ & $12.40 \pm 1.14$ & $55.33 \pm 11.5$ \\
\hline $\mathbf{A 2}$ & $18.60 \pm 2.30$ & $35.00 \pm 5.0$ \\
\hline $\mathbf{A 3}$ & $23.20 \pm 2.28$ & $24.33 \pm 7.37$ \\
\hline $\mathbf{A 4}$ & $23.20 \pm 2.28$ & $36.33 \pm 10.97$ \\
\hline $\mathbf{A 5}$ & $23.20 \pm 2.15$ & $29.67 \pm 8.12$ \\
\hline $\mathbf{A 6}$ & $23.53 \pm 2.47$ & $38.22 \pm 15.46$ \\
\hline $\mathbf{A 7}$ & $24.20 \pm 3.51$ & $38.67 \pm 16.12$ \\
\hline $\mathbf{A 8}$ & $22.30 \pm 3.23$ & $37.75 \pm 14.01$ \\
\hline $\mathbf{A 9}$ & $76 \pm 4.63$ & $0 \pm 0$ \\
\hline
\end{tabular}


Table.4 Effect of different formulation to the severity of blast disease in Green House test

\begin{tabular}{|l|c|c|}
\hline Treatment code & Isolates/mix cultures $(\%) \mathbf{~} \mathbf{\text { SD }}$ & inhibition over control $(\mathbf{\%}) \mathbf{\pm S D}$ \\
\hline $\mathbf{A 1}$ & $15.00 \pm 4.12$ & $11.80 \pm 4.55$ \\
\hline $\mathbf{A 2}$ & $21.20 \pm 2.86$ & $18.20 \pm 3.70$ \\
\hline $\mathbf{A 3}$ & $31.20 \pm 2.59$ & $28.00 \pm 2.35$ \\
\hline $\mathbf{A 4}$ & $29.60 \pm 2.07$ & $24.20 \pm 3.96$ \\
\hline $\mathbf{A 5}$ & $30.40 \pm 2.36$ & $26.10 \pm 3.67$ \\
\hline $\mathbf{A 6}$ & $22.47 \pm 7.53$ & $21.33 \pm 7.95$ \\
\hline $\mathbf{A 7}$ & $25.27 \pm 8.05$ & $19.33 \pm 7.66$ \\
\hline $\mathbf{A 8}$ & $24.25 \pm 7.26$ & $20.55 \pm 7.17$ \\
\hline A9 & $74.00 \pm 4.63$ & $0 \pm 0$ \\
\hline
\end{tabular}

Table.5 Storage period of bacteria consortium

\begin{tabular}{|l|c|c|c|c|}
\hline S.No & $\begin{array}{c}\text { Bacterial } \\
\text { consortium codes }\end{array}$ & $\begin{array}{c}\text { Formulated } \\
\text { carrier }\end{array}$ & $\begin{array}{c}\text { Month- 1 } \\
\text { Cells number }(\mathbf{C F U} / \mathbf{m l})\end{array}$ & $\begin{array}{c}\text { Month -3 } \\
\text { Cells number }(\mathbf{C F U} / \mathbf{m l})\end{array}$ \\
\hline $\mathbf{1}$ & $\mathrm{A} 1$ & Talc & $8.0 \times 10^{8}$ & $4.2 \times 10^{8}$ \\
\hline $\mathbf{2}$ & & suspension & $4.0 \times 10^{8}$ & $7.0 \times 10^{8}$ \\
\hline $\mathbf{3}$ & $\mathrm{A} 7$ & Talc & $6.0 \times 10^{8}$ & $4.4 \times 10^{8}$ \\
\hline & & suspension & $1.70 \times 10^{9}$ & $1.75 \times 10^{9}$ \\
\hline
\end{tabular}

Fig.1 The growth of $P$. oryzae (a) on plate conidia attached with conidiophores and mycelium (b) on leaf the symptoms on blast

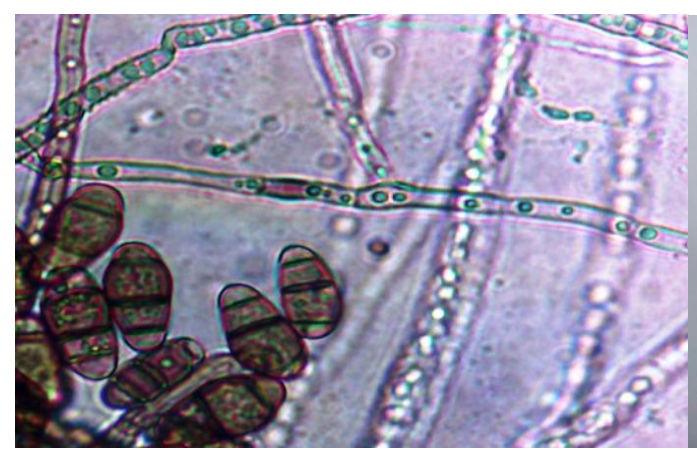

(a)

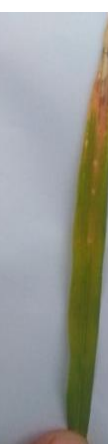

(b)

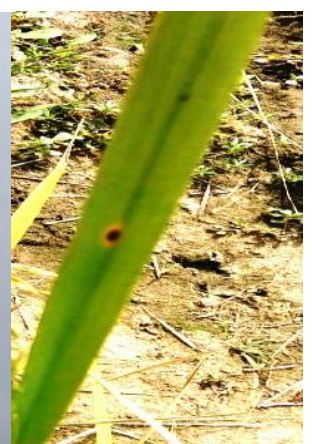

Fig.2. Effect various treatments of Bacteria Consortia against P.oryzae

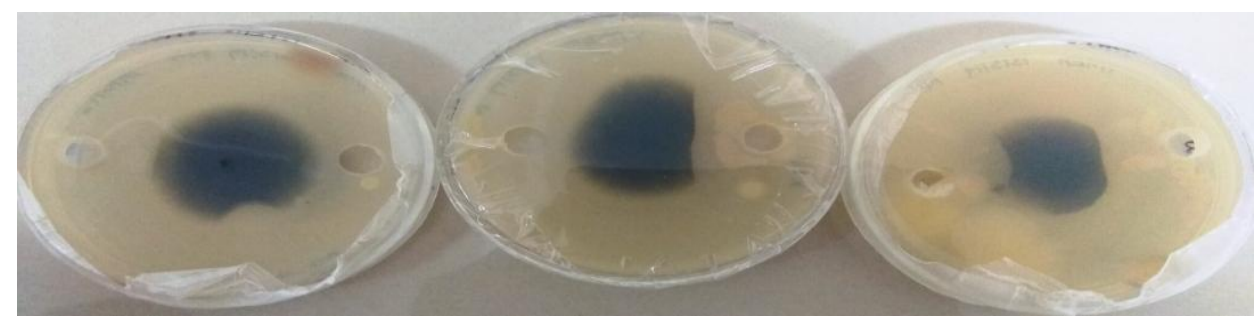


Fig.3 (a) Mean radial growth $( \pm \mathrm{SD})$ and $(\mathrm{b})$ percentage inhibition $( \pm \mathrm{SD})$ of $P$. oryzae using bacterial culture filtrate

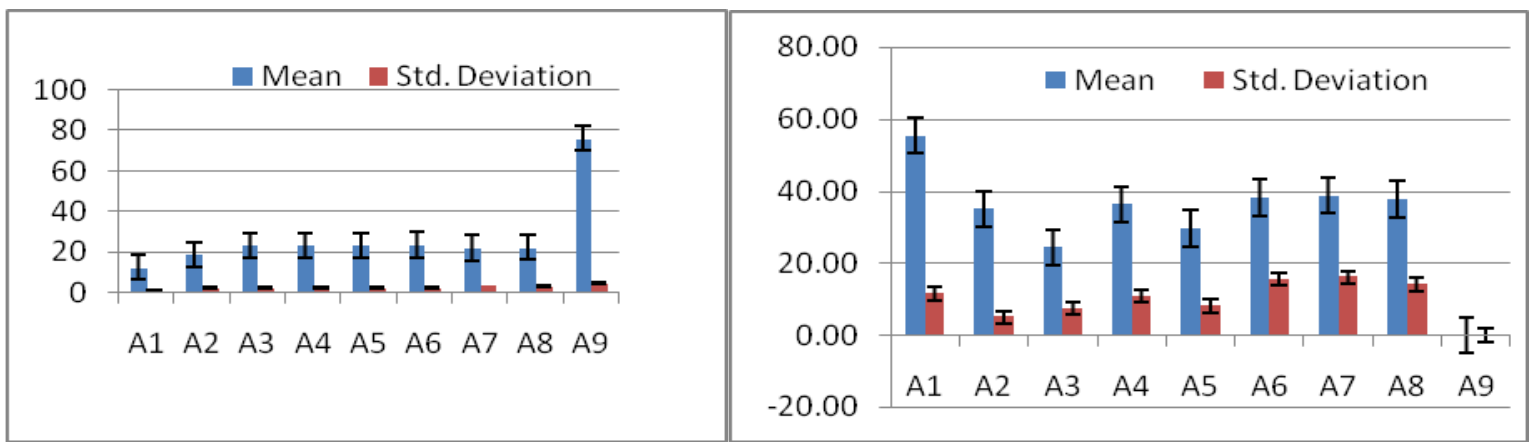

(a)

(b)

Fig.4 Severity of blast disease in Green House (a) Isolates/mix cultures (\%) \pm SD (b) inhibition over control $(\%) \pm \mathrm{SD}$

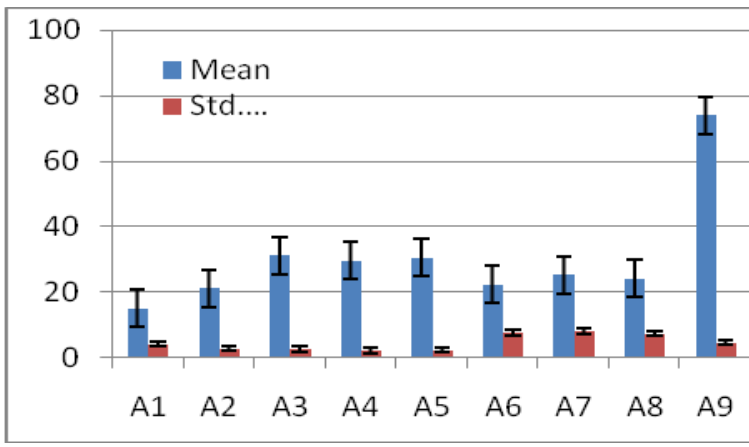

(a)

The effective formulation of A1 and A7 using talc and suspension were also reduced blast severity over $30 \%$ inhibitions in P.oryzae. The bacterial consortia isolates were mixed in the form of formulations, at month-1 and month-3 the quantity of Streptomyces albidoflavas (A1) decreased in average of 4.2 $\mathrm{x} 10^{8} \mathrm{CFU} / \mathrm{ml}$. The average of bacterial cells viability of A7 consortium was approximately $4.4 \times 10^{8} \mathrm{CFU} / \mathrm{ml}$. The overall cells viability was slightly decreased during period of storage (Table 5).

Rice cultivar PB1121 was studied, for apply the formulation of bacteria consortia against rice blast. The advantage of PB1121 is high potential productivity of 13.7 quintals of paddy per acre and has 137 days of maturity

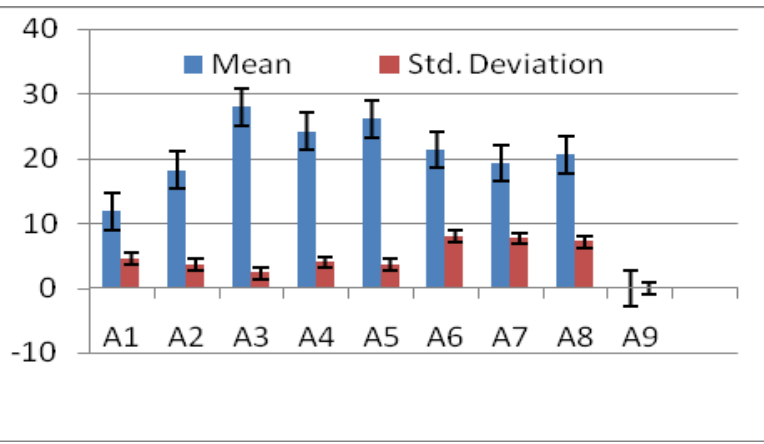

(b)

(Singh et al., 2018). P. oryzae the causal agent of blast disease is a type of fungi that is morphologically known to attack many types of grasses and weeds (Suryadi et al., 2013). It has long conidiophores and rarely branched. At the terminal end of the conidiophores, the conidia had oval shaped with pointed tip. in light microscope observation, conidia of $P$. oryzae consist of 2-3 cells, with hyaline brownish colour. The result demonstrated that rice blast disease symptoms begin to appear at 4 days after inoculation in greenhouse under moist condition characterized by the emergence of small spots $(\mathrm{Ou}, 1985)$. In recent years the use of bacterial bioformulations was used in crop protection and the product use as supplemented of an alternative to chemical control (Suryadi et al., 
2013). Dual culture test of bacterial consortia isolates showed the formulation, Streptomyces albidoflavus strain MK121 (A1) and Streptomyces griseocarneus strain MK186, Bacillus subtilis strain MK145, Bacillus cereus strain MK148 (A7) containing had the highest inhibitory effect compared to other bacterial isolates. Further inhibition test using bacterial cells cultures filtrate showed that A1 and A7 consortium could effectively suppress $P$. oryzae with the percentage inhibition of $90.59 \%$ and $89.00 \%$, respectively. The result of bacterial isolate selection for dual culture test was single active isolate MK121. $P$. oryzae fungi causing blast disease on rice $\mathrm{cv}$ PB1121.

Bacillus and Streptomyces are belong to Gram-positive bacteria that produced endospores and spore and can be a potential biological agent, due to its resistance to heat and drought conditions, thus suitable for applications in the field (Wayne et al, 2000; Compos, 2010). Similar in vitro test, the result of the greenhouse trial was highly effective because the bacterial formulations reduced blast disease. Mode of action in biological control agents are generally classified as activities of substances competition, parasitism, and antibiosis (Weller, 1988). The mechanisms of bacterial isolates particularly isolates MK121, MK186, MK145 and MK148 produced cell wall degrading enzymes such as chitinase and glucanase that can degrade cell walls of fungi. The mechanism of inhibition of bacterial consortia isolates against $P$. Oryzae produced by bacteria. Bacillus spp. produces a variety of antibiotics that are effective against bacteria and fungi, Bacillus subtilis has shows inhibition activity against fungi $P$. oryzae (Joshi and Gardener, 2006). Chitinolytic activity showed in several species of $B$. cereus (Mubarik et al., 2010). Streptomyces hygroscopicus OsiSh-2 supress riceblast disease $23.5 \%$ under green house and streptomyces UPMR54 reduce rice blast disease $67 \%$ and also improve the rice growth and yield (Chiharn et al,2019)

Single bacterial consortium and consortia treatment in this study showed variability of activity in rice blast. For example, the dual culture test showed that A3 treatment $(B$. subtilis 145) as single bacterium had minimum inhibitory activity against $P$. oryzae. However, the effect of $B$. subtilis 145 was seen on A5 and A6 consortium (mix cultures). Consortium A6 containing B.subtilis 145, B. Cereus148 and Streptomyces albidoflavus had inhibitory activity against $P$. oryzae much better than the A5 consortium containing B. subtilis 145 and Streptomyces griseocarneus alone. These results may indicate Streptomyces albidoflavus 121 plays synergistic role in the inhibitory activity of $P$. oryzae.

The bacterial consortium was allegedly a process of quorum sensing (QS). The interbacterial communication mechanism within use of chemical signaling molecules of bacteria is called auto inducer (AI). QS occur with various bacteria consortia but not in only bacteria consortium or interspecies (Suryadi et al., 2013).

The bacterial consortia efficacy of formulation application antagonistic to severity of rice blast disease was carried out during 14 days after inoculation. Treatment combinations of bacterial spraying formulation of the selected bacteria showed the suppressing activity against blast disease. Suspension-formulations of A1 and A7 showed potential suppressing effect that causing low blast severity than other formulations. Observation of bacterial cell viability was performed of mixing process of formulations, one month and three months after the formulation stored at room temperature $\left(32^{\circ} \mathrm{C}\right)$ and in refrigerator at 
$\left( \pm 4^{\circ} \mathrm{C}\right)$. The decrease in cell viability of bacteria at month-1 and month-3 may occur due storage adaptation that allows bacteria to survive or died.

Talc and suspension based formulations developed in their efficiency (Selim et al., 2005). It has been reported that several diseases are caused by exposure to harmful chemicals during spraying (Damalas and Eleftherohorinos, 2011). The reduced number of sprays was 5 for traditional pesticides compare with only 3 times for bacterial formulations would have a positive effect on health. The results obtained here pointed out the possibility use of bacterial consortium such as A7 in rice fields for blast disease suppression. However, further research is needed to elucidate in detail the mechanism of action of these strains and their compatibility with other components in integrated management of rice diseases (Suryadi et al., 2013).

In conclusion based on in vitro test, A1 (streptomyces albidoflvus MK121) and A7 consortium (Bacillus subtilis MK145, Bacillus cereus MK148, and streptomyces albidoflvus MK121)could suppressed the radial growth of $P$. Oryzae fungus with the inhibition of $12.40 \%$ and $53.33 \%$, respectively. It was shown that A1 (streptomyces albidoflvus MK121) suspension revealed good inhibitory producing the smallest of blast severity $(38.67 \%)$ under greenhouse condition.

\section{References}

[IRRI] International Rice Research Institute (1996). Standard Evaluation System for Rice.

Campos V. P., Pinho R. S. C. D., Freire E. S. (2010). Volatiles produced by the interaction between microorganisms potentially useful in the control of phytopathogens, Agrotec science. 34(3): 525-535

Chaiharn M., Theantana T. and Pathom-aree W.
(2019) Evaluation of Biocontrol Activities of Streptomyces spp. against Rice Blast Disease Fungi, Pathogens 2020, 9, 126; doi: 10.3390/pathogens 9020126

Damalas C. A., and Eleftherohorinos I. G. (2011). Pesticide Exposure, Safety Issues, and Risk Assessment Indicators, Int. J. Environ. Res. Public Health 2011, 8, 14021419; doi: 10. 3390/ijerph8051402

Dean, R., Kan, J. A. L. V, Pretorius, Z. A., Hammond-kosack, K., Pietro, A. D., Spanu, P. D., Rudd, J. J., Dickman, M., Kahmann, R., Ellis, J., \& Foster, G. D. (2012). The Top 10 fungal pathogens in molecular plant pathology. Molecular Plant Pathology, 13(4), 414-430. https://doi.org/10.1111/J.13643703.2011.00783.X

Dobermann, A., \& Fairhurst, T. H. (2002). Rice straw management. Better Crops International, 16(April 2002), 7-11.

FAO ,2020.crop prospects and food situation quarterly global report NO.1, march 2020

Fravel, D. R. (1988). Role of antibiosis in the biocontrol of plant diseases. Ann. Rev. Phytopathol. 26:75-91.

Gnanamanickam, S. S. and T. W. Mew (1992). Biological control of blast disease of rice (Oryza sativa L.) with antagonistic bacteria and its mediation by a Pseudomonas antibiotic. Ann. Phytopathol. Soc. Jpn. 58:380-385.

Joshi, R. and B. B. M. Gardener (2006). Identification and characterization of novel genetic markers associated with biological control activities in Bacillus subtilis. Phytopathol. 96:145-154.

Kumar, G., R. C. Sharma and S. N. Rai (2000). Biocontrol of banded leaf and sheath blight of maize by peat based Pseudomonas fluorescens formulation. Indian Phytopathol. 53:190-192.

Law, J. W. F., Ser, H. L., Khan, T. M., Chuah, L. H., Pusparajah, P., Chan, K. G., Goh, B. H., \& Lee, L. H. (2017). The potential of streptomyces as biocontrol agents against the rice blast fungus, Magnaporthe oryzae (Pyricularia oryzae). Frontiers in Microbiology, 8(JAN). https://doi.org/10.3389/fmicb.2017.00003 
Mubarik, N. R., I. Mahagiani, A. A. Putri, S. Santoso and I. Rusmana (2010). Chitinolytic bacteria isolated from chilli rhizosphere: chitinase characterization and application as biocontrol for whitefly (Bemisia tabaci Genn.). Am. J. Agric. Biol. Sci. 5:430-535.

Ou, S. H. 1985. Rice Disease. 2nd Ed. Kew Surrey: Commonwealth Mycological Institute. p.380.

Rabindran, R. and P. Vidhyasekaran (1996). Development of a formulation of Pseudomonas fluorescens PfALR2 for management of rice sheath blight. Crop Prot. 15:715-721.

Rabindran, R. and P. Vidhyasekaran (1996). Development of a formulation of Pseudomonas fluorescens PfALR2 for management of rice sheath blight. Crop Prot. 15:715-721.

Raman, T., \& Muthukathan, G. (2017). Field suppression of Fusarium wilt disease in banana by the combined application of native endophytic and rhizospheric bacterial isolates possessing multiple functions. Phytopathologia Mediterranea, 54(2), 241252. https://doi.org/10.14601/Phytopathol

Rukayadi, Y. and J. K. Hwang (2009). Pencegahan quorum sensing: suatu pendekatan baru dalam mengatasi infeksi bakteri. Medicinus 22:22-27.

Selim, S., J. Negrel, C. Govaerts, S. Gianinazzi and D. van Tuinen (2005). Isolation and partial characterization of antagonistic peptides produced by Paenibacillus sp. strain B2 isolated from the sorghum mycorrhizosphere. Appl. Environ. Microbiol. 71:6501-6507.

Singh V., Singh A. K., Mohapatra T., Krishnan
G. and Ellur R. K.(2018). Pusa Basmati 1121 - a rice variety with exceptional kernel elongation and volume expansion after cooking, Rice, 11(19), 1-10

Suryadi Y., Susilowati D. N. , Riana E. and Mubarik N. R.(2013). Management of rice blast disease (Pyricularia oryzae) using formulated bacterial consortium, Emir. J. Food Agric. 2013. 25 (5): 349-357 doi: 10.9755/ejfa.v25i5.12564

Suryadi, Y., D. N. Susilowati, K. E. Putri and N. R. Mubarik (2011). Antagonistic activity of indigenous Indonesian bacteria as the suppressing agent of rice fungal pathogen. J. Int. Environ. Appl. Sci. 6(4):558-568.

Tsukamoto, H., F. Tsutsumi, K Onodera, M. Yamada and T. Fujimori (1999). Biological control of rice leaf blast with Exserohilum monoceras, a pathogen of pathogen of chinochloa species. Ann. Phytopathol. Soc. Jpn. 65:543-548.

Waters, C. M. and B. L. Bassler. 2005. Quorum sensing: cell-to-cell communication in bacteria. Annu. Rev. Cell Dev. Biol. 21:319346.

Wayne, L. N., N. Munakata, G. Horneck, H.J. Melosh and P. Setlow (2000). Resistance of Bacillus endospores to and extreme terrestrial and extraterrestrial environments. Microbiol. Mol. Biol. Rev. 64:548-572.

Welfare, F., \& Welfare, F. (2019). Agricultural Statistics at A Glance 2019 Agricultural Statistics at a Glance 2019.

Weller, D. M. (1988). Biological control of soilborne pathogens in the rhizosphere with bacteria. Ann. Rev. Pythopathol. 26:379407.

\section{How to cite this article:}

Nalini Singh and Jasvir Singh Brar. 2020. Biological Control of Rice Blast Disease (Pyricularia oryzae) using Bacterial Consortia Formulation in Malwa Region (Punjab). Int.J.Curr.Microbiol.App.Sci. 9(08): 3939-3948. doi: https://doi.org/10.20546/ijcmas.2020.908.453 